\title{
REWRITING STEREOTYPES ON SPAIN: \\ UNVEILING THE COUNTER-PICTURESQUE \\ IN KATHARINE LEE BATES
}

\author{
Alberto Egea Fernández-Montesinos \\ Universidad Pablo de Olavide, Sevilla
}

\begin{abstract}
This article analyzes the use of the concept of the picturesque in Katharine Lee Bates's travelogue Spanish Highways and Byways (1900). By comparing Bates's text to previous travel narratives, the essay explores how stereotypes written about Spain are challenged and reformulated within the framework of imperial discourse. Bates's political and ideological agenda attempts to construct an alternative discourse through the use of what I have called the counter-picturesque. The essay contributes to the study of travelogues written by American women and to the field of imagology as related to Spain.
\end{abstract}

KeYwords: Katharine Lee Bates, travel literature, Spain, picturesque, counter-picturesque, image, stereotypes.

\section{LA REESCRITURA DE ESTEREOTIPOS SOBRE ESPAÑA: DESVELANDO LO ANTIPINTORESCO EN KATHARINE LEE BATES}

\section{RESUMEN}

El artículo analiza el uso del concepto de lo pintoresco en el libro de viajes Spanish Highways and Byways (1900) de Katharine Lee Bates. Mediante la comparación de la obra de esta conocida escritora norteamericana con textos de viajeros anteriores es posible apuntar cómo se cuestionan y reformulan estereotipos sobre España en el contexto del discurso imperial. El trasfondo ideológico de la autora intenta construir un discurso alternativo mediante el uso de lo que he llamado lo antipintoresco. El trabajo contribuye al estudio de la literatura de viajes escrita por mujeres estadounidenses y al concepto de imagología en relación con Espańa.

Palabras Clave: Katharine Lee Bates, literatura de viaje, España, pintoresco, antipintoresco, imagen, estereotipos.

[The] theory and practice of the Picturesque constitute the major English contribution to European aesthetics

(Watkin 1982: vii).

The search begins for those specific characteristics that distinguish a nation amidst its neighbours; the logic is one of the positive self-valorization highlighted by representing other peoples negatively (Beller \& Leerssen 2007: 6).

DOI: http://doi.org/10.25145/j.refiull.2019.38.004

Revista de Filología, 38; enero 2019, pp. 61-78; ISSN: e-2530-8548 
Katharine Lee Bates (1859-1929) is an American writer well-known for her hugely popular poem used as the lyrics to the patriotic ballad «America the Beautiful», considered by some the true American anthem. Bates was an accomplished academic with dozens of publications who served as the head of Wellesley's English Department for many years, at a time when women faced severe difficulties in academia. She was an active feminist and an advocate for women's rights who lived an intense Boston marriage with her colleague, Katharine Coman.

Bates was an avid traveler and visited Spain in 1899, shortly after the Spanish-American War. In this intensive six-month trip, she produced two books about Spain, twenty-one chronicles for The New York Times and numerous poems. While «America the Beautiful» has received immense praise and study, her travel book Spanish Highways and Byways, published in New York in 1900, and the rest of her travel texts remain unexplored despite being well crafted travelogues and major contributions to the study of modern Spanish identity politics. This paper analyzes the use of the concept of the picturesque in Bates's travelogue. The aim is to highlight the influence of aesthetics discourse, especially picturesque representational language, on travel writing, that is, to introduce the theoretical aspect of aesthetics analysis and imagology in the field of travel studies written by women. There has been an extensive mapping of American travel writing on Spain mostly centered on the same key male figures: Irving, Ford and Borrow. However, the role that women travelers played in the representation of Spain remains relatively unexplored. I hope this study contributes to unveiling new perspectives by women writers on the portrayal of Spaniards.

Regarding the structure of this essay, after a general introduction with definitions and references to various theoretical approaches, I will conduct a brief discussion of the picturesque as an aesthetic category. Subsequently, I will focus on a close textual analysis of Bates's use of the term picturesque. The central body of the article is dedicated to comparing Bates's rewriting of previous discourse on Spain relative to the portrayal of landscape and subjects as related to social and cultural issues. A substantial part of this essay deals with analyzing her dialogue with imperial discourse both questioning and reformulating stereotypes about Spain. The remainder of the paper explores the conflicting discourses that are speaking through Bates's works, her political and ideological agenda and her attempt to produce an alternative discourse through the use of what I have called the counter-picturesque.

The themes addressed in this essay engage with various debates about representation and travel, culture and encounter, and hegemony and discourse, in line with key contributions by Stephen Copley, Joep Leerssen, and Manfred Beller in the field of picturesque aesthetics and imagology. The theoretical foundations are based on gender studies with recent contributions by Susan S. Friedman, Elizabeth Bohls, Jennifer B. Steadman, Cheryl J. Fish, and Lila M. Harper. Previous literature in the area of postcolonial theory has pointed to the representation of the picturesque in American and British travelogues written by women in India, the Middle East and Latin America, but has neglected the case of Spain. With regard to the study of the image of Spain as presented by women travelers, very few approaches have been made. As pointed to by Gifra-Adroher, the contribution of women to travel 
writing on Spain undoubtedly deserves more attention (2000: 188). Bates continues a tradition of women writers begun decades earlier by Caroline Cushing in the «deconstruction of the myth of the rough peninsular crossing only fit for male travelers" (Gifra-Adroher 2000: 229). This essay tries to bridge those gaps addressing both the use of picturesque aesthetics in the case of Spain and the analysis of a woman writer.

The objective is to explore how Bates reworks the picturesque variety used by her predecessors, and how the narrative strategies used in the text signal a rejection of pre-established stereotypes and bring up a gesture against previous travel imagologies. The definition of image used in this essay relies on the contributions by Manfred Beller and Joep Leerssen in their key compilation to the field of Imagology: «The mental or discursive representation or reputation of a person, group, ethnicity or 'nation', therefore it does not refer to the pictorial aspect of a visual depiction [...] All 'national characters' are imagined just because their reality relies on imputations rather than on testable facts» (Beller \& Leerssen 2007: 342).

The essay will focus on ways in which Bates employed the textual instability inherent in the concept of the picturesque to present various critiques of previous travel writers' authority. In that sense, Bates's social agenda to reshape the stereotypical image of Spaniards is presented through subtle literary strategies'. Bates's politicization of the picturesque is evident in Spanish Highways and Byways and entails an acute confrontation with the predominant imperial discourse ${ }^{2}$. The remarkable achievement of this text is how Bates utilizes the language of Empire as a rhetorical weapon against the same foundational principles of that system, even if she cannot entirely leave imperial dynamics behind.

Spanish Highways and Byways received little critical attention when it was published in 1900. Despite Spain being an intensely studied topic at the time due to the Spanish-American War of 1898, it seems that all interest and critical studies have chosen to elaborate on Bates's hugely popular poem "America the Beautiful». The lack of critical reviews about her travelogue on Spain contrasts with the amount of articles she published in The New York Times and her numerous invited lectures about

1 The definition of stereotype used here is the verbal expression of an opinion concerning social groups or individuals as representatives of such groups [...] wrongfully simplifying and generalizing terms and with an emotionally valorizing tendency (Beller \& Leerssen 2007: 431-432). Regarding cliché, this expression refers to a traditional form of human expression that -due to repetitive use in social life- has lost its original, often ingenious, heuristic power. Unlike stereotypes, which also contain valorizing moral and metaphysical aspects, clichés are merely reductions of a formulaic expression (Beller \& Leerssen 2007: 297).

2 The definition of imperial discourse is based on the works by Cheryl J. Fish and Jennifer B. Steadman. Fish comments that imperial discourse is the product of a unique combination of colonial expansion, economic domination and intellectual interventionism. In some cases, women travelers had to journey to outposts of conflict and imperial expansion due to the difficulties in participating in discussions on social and political topics back home (Fish 2004: 3-6). The encounter with cultural alterity in nineteenth-century travelogues was a product of both hegemonic expansion and an intellectual urge for investigation (Steadman 2007: 56). 
this convoluted episode of U.S.-Spain relations ${ }^{3}$. Bates published detailed accounts about Spain in her 21 articles that appeared in The New York Times between 1899 and 1900. In addition, she was invited to deliver public lectures on Spanish topics in various universities and other relevant institutions on the East Coast (Burgess 1952: 137). It is important to study the Image of Spain exactly at that key historical moment since, as commented by Manfred Beller: "In times of political tension, conflicts of war, these images rise up or are called up from an unconscious inventory of images and generalized prejudices about the other» (Beller \& Leerssen 2007: 11).

This avid interest in Spain at the fin de siècle was preceded by other waves of infatuation with the country in the first decades of the nineteenth century with the successful romantic novels, travel journals and illustrated books by best-selling writers such as Washington Irving and Richard Ford, and academic writings by Hispanists such as George Ticknor. Bates arrives in Spain at that second key moment in the construction of the image of Spain, described by Gifra-Adroher as a shifting moment, moving from a dark, fanatic, cruel, Catholic country to a more pleasing site: a romantic land of picturesque settings and hospitable dwellers. What this study tries to analyze is the shift of the dynamics, where the image of Spain for Bates changes from the original assessments, based on the stereotypes of idleness and violence, to other views underlining positive traces, such as hospitality and industriousness. Bates's texts participate in that key transformational episode by actively participating in reshaping Spain's national imagology.

In the popular perception, Spain was a country of political agitation and social unrest. In fact, in her first attempt to enter Spain in 1898, Bates was kept in France for a few months unable to cross the frontier due to the Spanish-American War. A predominant cliché presented a country populated by vicious individuals of an idle nature, undeserving of the place of aesthetic beauty and picturesque landscapes. The images of the Spaniard oscillated between negative perceptions of bandits, beggars and scoundrels, and positive ones, like the romantic view of flamenco beauties and brave toreadors. Thus, like most ethnic stereotypes, images of Spaniards had been dualistic and Manichean. Romantic travelers had perpetuated the tradition of Spain as an exotic peripheral location, both geographical and imaginary, favoring negative views with obscure representations. What this study tries to understand is the nature of the dynamics where the image of Spain shifts between contrasting modalities and opposing judgements when compared to other writers.

Formerly, travelers had celebrated the beauty of the landscape while simultaneously denigrating the locals, using an assortment of vicious defects and drawbacks. In that sense, Spain as a foreign land had inspired lack of understanding, apprehension, fear or loathing. This contradictory discourse, used to praise the country

3 The interest in Spain grew exponentially due to the Spanish-American War. A search on the amount of articles written about Spain in The New York Times archives offers revealing data: in 1905 the number of articles dedicated to Spain tripled compared to 1895 (from 5,691 to 16,690 references). The case is significant since a similar search about relevant nations such as England or France barely doubles in number in the same time periods. 
while censoring the inhabitants, is reconfigured in Spanish Highways and Byways. Bates opts for an alternative image, to elicit admiration and delight. This positive appreciation of the exotic is, in some respects, the very opposite of ethnocentrism: the foreign country is positively assessed and, in many cases, seen as a preferable alternative to one's domestic culture. According to Manfred Beller, in most cases, the mechanics behind the construction of the imagology of a foreign land is a search for those specific characteristics that distinguish a nation from its neighbours; the logic is one of positive self-valorization, highlighted by representing other peoples negatively (Beller \& Leerssen 2007: 6). On the contrary, in Spanish Highways and Byways, the description of productive locals leaves the reader slightly surprised but, most importantly, aware of the constructed nature of previous prejudiced accounts. In this sense, now the figures are not only deemed as picturesque appendages in the landscape complementing the beauty of nature ${ }^{4}$.

A key term for understanding this rewriting process is the recurrent and inescapable category of the picturesque ${ }^{5}$. Bates employed the aesthetic instability inherent in picturesque "variety" in order to voice different critiques of masculine authority and to articulate her emergent independence as a voice in travel writing. What is unique to Bates is that she applied the principles of Oriental picturesquism to Spanish models, which is a logical paradox if we consider Spain an orientalized East within the West. The picturesque serves her to describe not only art and nature but also denizens and their subjectivity. The first question that comes to mind is why the term picturesque is so frequently used by Bates when describing Spain, and also why this category is so frequently repeated in the descriptions of foreign encounter narratives ${ }^{6}$. Before completing the textual analysis, which is the object of this essay, the following paragraphs establish definitions of the picturesque and contextualize its historical relevance in travel literature.

There has been an increasing interest in theories and definitions of the picturesque in recent decades. The purpose of this section is not to elaborate on this hackneyed debate but rather to outline a brief definition of how the picturesque

${ }^{4}$ Many previous travelers were only interested in the Oriental exoticism of Spain rather than in the sociohistorical and cultural events of the country. Gifra-Adroher mentions the case of Washington Irving, mostly interested in the picturesque nature of the Spaniards and the Oriental charm of architecture (2000: 127).

5 The word picturesque is used by dozens of travelers who wrote on Spain. Among them, Henry Swinburne, Francis Hopkinson Smith, Nathaniel Armstrong Wells, David Roberts and many others. The word is also used in other curious examples such as volume III of the hugely popular collection Picturesque Europe by Bayard Taylor whose cover is illustrated with the very Spanish and picturesque Alhambra.

${ }^{6}$ The aesthetic categories of the Beautiful, the Sublime, and the Picturesque are key to understanding any modern piece in literature and the visual arts. The discourse of the picturesque operated in narratives, poetry and painting, and became a commonplace for textual and aesthetic criticism since the eighteenth century. The term picturesque was used and abused in many nineteenth-century aesthetic books and travel narratives. Its overuse is criticised by many authors, among them William Combe. 
relates to stereotyping and to the construction of an imagology of Spain. Various authors have analyzed and contested the founding fathers of the discourse of the picturesque: William Gilpin, Uvedale Price and Richard Payne Knight ${ }^{7}$. Recent contributions in the field are those by Stephen Copley, Elizabeth Bohls, Persephone Braham, and Esther Ortas, who have focused on the links between aesthetics and social changes, national stereotypes, and gender in writing and reading travelogues. The difficulties in establishing a clear definition of the picturesque are already pointed out by Price, one of the original theorists: «There are few words whose meaning has been less accurately determined than that of the word picturesque» (1810: 8). The main difference between Price and Knight is that the latter believes that objects themselves do not possess picturesque properties but that it is the viewer who can produce that picturesqueness through associations. This interesting insight is what guides the current analysis: how Bates, as viewer, produces the picturesque and transforms it from what had been constructed.

The picturesque can be very different phenomena, such as romantic ruins, landscapes and ethnographic subjects, exotic topoi, archaeological items, and old times, literary figures, and even rustic communities untouched by modernity, or just the effects of passing of time on cultural heritage. For some, the picturesque seems to be that which escaped the process of modernization experienced in industrialized nations such as England and the US: «The picturesque legitimized and nourished a connoisseur taste for natural scenery and architectural and social subjects that had conspicuously escaped modernising improvement» (Andrews 2010: 179). Among the many types of picturesqueness, one category which has not been explored is what I have called the counter-picturesque. This neologism designates those occasions on which the picturesque is contested, questioned or reconstructed. The counter-picturesque is not reiterating the same pictorial beauty in certain commonplaces as presented in previous accounts. This resistance to register the supposedly picturesque nature of those lands and to present alternative views is what differentiates Bates's text from previous travelogues.

The counter-picturesque is defined as an effort to elaborate on a hackneyed topic presenting it from an alternative point of view and providing evidence and examples of how cultural perceptions can be rearranged when seen in a different light. In the case of Bates, the counter-picturesque entails the use of textual devices such as quotation marks, play-on-words and irony, and placing these views at key textual positions, such as arrival scenes. These examples are presented in a consistent manner, that is, not only in isolated cases in a single work, but rather in different texts of various typologies, such as happens in Bates's main travel book Spanish Highways and Byways and also in her articles and personal letters on Spain. The

7 Price was the first to consider the picturesque as a category distinct from both the sublime and the beautiful, and emphasized it as fundamental to genres other than painting by tracing the word's etymology to the Italian pittoresco, which referred not only to pictorial delineation but expanded to a whole turn of mind (1810: 618). 
counter-picturesque undermines previous populist and bourgeois accounts, unlike what Bourdieu presents in his theory on dominant aesthetics, by providing agency and subjectivity to those subjects traditionally presented stereotypically ${ }^{8}$.

In fact, what is unique to Bates's use of the picturesque is that her text overcomes the barrier of landscapes, locations and vistas to approach subjects, people and habits. Her picturesquism evolves from the sphere of landscapes to that of social characters: from the previous picturesque, originating in caves, quarries and ruins there is an increasing interest in social issues and human characters. There is a clear shift in the focus of attention from interest in the physical to the human side of the trip; from things picturesque to a more modern human picturesque. Previous accounts present Spain as an Oriental scenario within the West, a playground for entertainment, the location of sensuality, difference and exoticism. Bates's picturesque is not the stereotypical depiction of the Spanish landscape and the delineations of primitive bandits and sensual flamenco dancers, but rather instances trying not adhere to the typology of what has been considered picturesque by critics. In the light of this reading, it is possible to rethink negative assessments common in modern literary studies which provide a misleading interpretation of both the picturesque and its influence?

"America the Beautiful», the renowned poem written by Bates after her trip to Colorado, is also picturesque and scenic. However, Bates's American patriotism in this piece expressing devotion appears to be an interesting contradiction compared to her defense of Spain in Spanish Highways and Byways. The decade of 1895-1905 (when both works were published) was highly patriotic in the United States, a time full of flag-waving, as Melinda Ponder points out. Bates participates in this burst of patriotism during Teddy Roosevelt's presidency, right after the Spanish American War, when the United States was becoming an imperialistic power. Nevertheless, this is also the time when Bates writes her letters and diaries from Spain in which she tries to help Americans see the world from the point of view of the Spaniards. Bates's texts try to develop empathy in her readers with regard to alternative views, such as the Spanish soldiers who had been victimized in the Spanish American war

${ }^{8}$ Bourdieu comments on the picturesque in a parallel manner: «Like the photographic recording of the social picturesque, whose populist objectivism distances the lower classes by constituting them as an object of contemplation or even commiseration or indignation, the spectacle of the 'people' making a spectacle of itself, as in folk dancing, is an opportunity to experience the relationship of distant proximity, in the form of the idealized vision purveyed by aesthetic realism and populist nostalgia, which is a basic element in the relationship of the petite bourgeoisie to the working or peasant classes and their traditions» (2000: 207).

9 This is one part of a larger project on the evolution in meaning of the word picturesque over the past two centuries. The key references to explain the initial approach to this project are commented in Alberto Egea (2009: 9-48). A critical bias may be perceived when modern critics assess the meaning of the picturesque in works of art from different time periods without considering the different definitions the word has had. The change in meaning towards a more pejorative sense needs to be addressed. The principle of the picturesque has to be reassessed using historical dictionaries from the different decades in which this word was used. 
and also the abuses of the American army in the Philippines. Therefore, it is very interesting to note how the author of the key patriotic hymn challenges the very expansionist principles of that empire: an enthralling paradox.

The word picturesque is used over twenty times in Spanish Highways and Byways to describe situations, characters, habits and locations. In fact, it is the very first adjective used to describe Spain, already in the Preface, praising the picturesque, poetic charm of the Peninsula and the graciousness of Spanish manners (1900: i). The book's arrival scene takes place in the tiny village of Pasajes in the Basque Country, where Bates witnesses the peasants working extremely hard. The description contradicts the stereotypical view of Spaniards as lazy idle characters perpetuated in previous accounts: "One of our preconceived ideas went to wreck at the very outset on the industry of the Basque Provinces. The 'lazy Spaniard' has passed into a proverb» (1900: 2). This view of the town of Pasajes is relevant since it is the first thing Bates notes upon arrival.

With this use of the category of the picturesque directly at the beginning of the text, the reader perceives a clear change in the stereotypical idleness applied to Spaniards by previous travel writers. Bates's human-centered version of the picturesque scene emphasizes the dignity of the labouring men and women who inhabit the landscape. Infusing the picturesque with hard working and dedicated characters, Bates self-consciously modifies the aesthetic discourse bringing a positive and productive vision of the people. Adding to this narrative, Bates published the article «Hardships of the Middle Class» in The New York Times on 12 February 1899, describing the Spanish middle class in these terms: «lusty element of kindly, honest, hard-working, self-respecting people» (1899-1900: 12). In this sense, Bates becomes a good example of what Shirley Foster and Sara Mills have called the questioning of imperial discourse.

The relevance of arrival scenes in travel literature has been pointed out by Mary Louise Pratt who defined them as «potent sites for framing relations of contact and setting the terms of its representation» (1992: 78-80). These images are visual instances where the writer sees the "other» for the first time. Therefore, this arrival scene serves to frame the tone for the whole text ${ }^{10}$. This textual image together with the reference in the preface summarizes the two main topics of this paper: the use of the picturesque as an aesthetic device and the questioning of stereotypes as a rhetorical mechanism. In this sense, the purpose of Bates's first

10 Spanish Highways and Byways presents a total of forty visual images, that is, illustrations. However, their aim is not to underline the picturesque nature of Spain. They are not images of decay, roughness, ruins or irregularity, as in many other illustrated books on Spain such as Julia Clara Pitt Byrne's Cosas de España and Olive Patch's In Sunny Spain: its People and Places. Out of the twenty textual references to picturesqueness in Spanish Highways and Byways, only four of them refer directly to the illustrations in the book: the Village of Pasajes, Filling the Water-jars, Gypsy Tenants of an Arab Palace, and Dancing the Sevillana, A Roman Well in Ronda and Bull-fight of To-day (1900: $4,62,112,258,290$, and 414). The relationship of visual images and text are merely anecdotal, and therefore they are not explicitly commented on in this essay. 
use of the word is no other than to question this major stereotype about Spain, perpetuated by previous romantic travelers during decades in the Modern period: the idle Spaniard. Stereotypes and clichés of national characters are often invoked ironically as, precisely, clichés with a knowing wink from author to reader, as Joep Leerssen comments (quoted in Beller \& Leerssen 2007: 74).

Bates entitles her first chapter «The Lazy Spaniard». However, curiously enough, the title appears in quotation marks. In fact, it is the only chapter of the whole book to appear in quotation marks (besides the chapter "O la Señorita!» which requires quotes since it is written in a foreign language). Therefore, from the way the title is presented, the reader assumes that the concept of "the Lazy Spaniard" is being borrowed from previous discourse. Farmers, teachers and shepherds and their wives are described as very hard-working people at the same time that Bates uses the title of the chapter, «The Lazy Spaniard», to challenge this prevailing cliché (1900: 2-8 $)^{11}$. At the same time that the use of the quotation marks suggests that this cliché might need rethinking, the text is clear in affirming early on page 2: "the laborious Spaniard can no longer be ignored». Also, a few pages later, she uses the expression «lazy Spaniard» again with subtle irony: «But all her week's work looked to us impossible. We had known diligent teachers in the United States; this 'lazy Spaniard,' however, not only keeps her Kindergarten well in hand from nine to twelve, but instructs the same restless mites in reading and counting» (1900: 7).

Laborious farmers and diligent workers are the alternative picturesque for challenging previous commonplaces: «peasants ploughing the very mountain top, picturesque figures against the sky» (1900: 364). It is clearly a more dignified presentation of the laboring nature of Spaniards than average previous accounts. Bates revises the canons of scenic description to make a seamless transition from mere motionless characters with just an aesthetic presence to the active hardworking individual. Underlining the effort and dedication of the workers serves to break the frame of picturesque convention to make room for a more humane mode of representation. In this case, her use of counter-stereotyping contests previous commonplaces: "Having re-formed our concept of a Spaniard to admit the elements of natural vigor and determined diligence» (1900: 11). Bates enters the discourse of the picturesque, a mostly male field, and transforms it to her benefit. Zoë Kinsley refers to Dorothy Richardson's travel journal strategies in this manner: «The picturesque simultaneously enables her to organize and bring coherence to her experiences of the unfamiliar landscapes of travel, while allowing her the opportunity to enter a predominantly male discursive forum and offer her own interpretation of its ideology» (2005: 611).

${ }^{11}$ Many foreign travelers had criticized Spaniards for not being productive enough and dedicating their time to enjoying life. It is striking that those criticisms were formulated when the travelers were visiting the popular celebrations throughout the country. Some of them regret that, it being, unfortunately, the time of a fair, and therefore they could not see anyone at work. They then extrapolate the specific case to the whole nation therefore generalizing about the country as indolent and festive. As Copley ironically comments, the striking absence at the centre of this claim, however, is any consideration of this critic's position as the leisured observer of the scene (1994: 51). 
In traditional travel literature, «figures in picturesque landscape were typically peripherals, faceless, grouped as carefully as trees or cattle, and included solely as ornaments» (Bohls 1995: 118). In the case of Bates, some of these characters, such as workers, gypsies and beggars acquire distinct subjectivities. While picturesque aesthetics usually avoids subjects and subjectivity, Spanish Highways and Byways succeeds in portraying the personalities and problematics of gypsies. In her beautiful description of the Alhambra, Bates introduces outlaws not as mere decorative pieces (as we can see in most travelogues and chronicles of the time) but as real people who suffer oppression and marginality (1900: 136-137). The all-time favorite character of the gypsy, amply portrayed as demeaning in Borrow's and Byrne's highly prejudiced texts ("fortune tellers, dancers and beggars»), is staged under a different light in this travelogue. Bates mentions George Borrow to point to the major differences she has appreciated as compared to the account of this classical gypsy authority: "Yet there has been an improvement ... The gitanos are not such ruffians as of old, nor even such arrant thieves ... There are wealthy gypsies, whose wives and daughters go arrayed with the utmost elegance of fashion, in several Spanish cities. Seville has her gypsy lawyer, but her gypsy bull-fighter, who died two years ago, was held to reflect even greater credit on the parent stock» (1900: 133). Apart from these occasions, it is true that Bates finds it hard to escape from the demeaning mainstream discourse on gypsies and the tourist guide nature of her text which required her to warn travelers on the dangers of Spanish bandits and gypsies.

Regarding how people are presented in picturesque travelogues, David Marshall comments: «the picturesque represents a point of view that frames the world and turns nature into a series of living tableaux. It begins as an appreciation of natural beauty, but it ends by turning people into figures in a landscape or figures in a painting» (2005: 414). Human figures in the picturesque scene are frequently reduced to faceless ornaments, like Ford's or Brooke's ubiquitous banditti. In traditional travel narratives, the locals were sometimes considered part of the landscape, as commented by James Buzard: their objectification was part of this panorama of the nineteenth century. They could neither be heard nor recognized as subjects. They were presented as a mere amusement for the travelers. This can be seen in many examples of travel descriptions from trains which present faceless and soulless subjects as dehumanized portraits (1993: 189).

On the contrary, the relevant feature of Spanish Highways and Byways is how it tries to do exactly the opposite by approaching the people and establishing a dialogue with them. What allows Bates a closer integration and understanding of Spanish subjects is her mastery of the Spanish language, which allowed her to establish a special communion with Spaniards. Bates had ample conversations with Spanish factory workers and mingled with farmers, gypsies and people from all walks of life in their own language, in which she acquired high proficiency ${ }^{12}$.

12 Bates began learning Spanish in 1898, the year before her trip to Spain. She continued her study of Spanish, Italian, German and French at the Berlitz School in London (Ponder 2017: 180). 
She spent evenings talking to the gypsies in Granada's Albaicín and kept animated conversations about politics with friends in Madrid, which allowed her to know firsthand how corruption and bad government had impoverished Spaniards' everyday life (11). Already in the first chapter, Bates talks to a group of workers who tell her about the misery and sorrow that surrounds them and their families (1900: 4). In fact, Bates presents herself more inclined to talk to humble workers than refined politicians: «In the course of the month, English and Spanish callers climbed the hill to us and encompassed us with kindness, but we still maintained our incorrigible taste for low society and used to hold informal receptions on sunny benches for all the tatterdemalions within sight» (1900: 33).

What other travelogues had considered picturesque, Bates recategorizes. From gypsies to landscapes, from coachmen to water bearers, Bates tries not to objectify destitutes and marginals. Here rustics, beggars or gypsies are not idealized and their living conditions are not sublimated in anesthetized bucolic descriptions. Bates visits an asylum, and later visits a school for women in Vigo, and in the same chapter she manages to get a "touch of genuine fellowship" with Galician peasants (1900: 441). What begins as borders of difference ends as the space of intercultural mixing. Even if the discourse of the picturesque had abounded in wistful gazes toward untouchable objects, Bates presents a social agenda rather than a mere aesthetic one when using the category of the picturesque. In that sense, her portrayal of the people is also counter-picturesque since Bates does not choose to elaborate on abbey ruins, flamenco and bullfighting, but instead deals with the social problems of factory workers and the need for reform in education to include women (1900: 209) ${ }^{13}$.

Another relevant issue is how Spanish Highways and Byways presents ordinary Spaniards and relates to their everyday life. Bates praises Spanish hospitality towards strangers and celebrates innkeepers who had been criticized by previous travelers in the same location and in the same year, such as her experience in Sanlúcar (1900: 270). According to Bates, shopkeepers, hosts, neighbors, or just passersby are extremely courteous and kind (1900: 60, 73, 77, 156, 378), which serves to undermine the ideas of violence, cruelty and bad manners presented in earlier accounts. Her biggest surprise comes when she expects Spaniards not to receive her kindly because of the recent Spanish-American War but is pleasantly surprised following such a touching welcoming from everyone (1900: 29). In general terms, Spaniards are highly praised: «The civilization of Spain [...] is still in many aspects finer than

In Spain, more of her stays were in Spanish homes, where she could practice the language. In Spanish Highways and Byways, she translates poems, riddles and stories from original Spanish sources. Her mastery of the Spanish language is proved by her 1909 published translation of Romantic Legends of Spain by Gustavo Adolfo Bécquer (Burgess 1952: 126).

${ }_{13}$ Bates's vindication of women's rights is already present in her childhood diary written when she was only eight: "Girls are a very necessary portion of creation. They are full as necessary as boys. [...] Sewing is always expected of girls. Why not of boys? Boys don't do much but outdoor work. Girls work is most all indoors. It isn't fair» (quoted in Burgess 1952: 4). 
our own. In everything that relates to grace and charm of social intercourse, to the dignified expression of reverence, compassion, and acknowledgment, Spain puts us to the blush" (Bates 1900: 39).

By using these corrections and disapprovals, Bates is disallowing previous travel book writers such as Richard Ford and Karl Baedeker. She sweeps away the two leading guides of the day, dismissing some as inaccurate: "On we go over the Bridge of Alcantara, wrought aeons since by a gang of angry Titans -the guidebooks erroneously attribute it to the Moors and Alfonso the Learned» (1900: 274). Baedeker is also wrong when describing their Palencia inn: «But even Baedeker is fallible, and on arriving at the Gran Hotel Continental, we were met by all the Castilian dignity and grave kindliness of greeting” (1900: 283).

On a parallel issue, Bates's political position was certainly liberal and this may be detected through her defense of workers' rights and her criticism of capitalism $^{14}$. Curiously enough, she attended a political meeting about the 1899 Montjuïc prisoners with the presence of Pablo Iglesias ${ }^{15}$. In spite of this, and due to college restrictions and her public image as a university professor, it is understandable that Bates would not want to be very open about her progressive ideology. This liberal agenda contrasts with the vision offered by most of her biographers, such as the book written by her niece, Dorothy W. Bates Burgess ${ }^{16}$. In some of her letters, Bates challenges the foundations of capitalism, sympathizes with members of the socialist party, and expresses her rejection of the religious control of Wellesley College faculty by the provost. In that sense, Bates's revision of the aesthetics of the picturesque must be understood as part of her liberal political project of exploring otherness and pointing out social inequalities.

All in all, after reviewing the references to the picturesque in Spain, what is at stake in Spanish Highways and Byways is a statement of the systematic inequalities and problems of Spanish society. Bates's liberal political project of extending rights and reducing social inequality both in Spain and back home is

${ }_{14}$ Bates used a male pseudonym, James Lincoln (Jay), (after her admired president), to publish many poems and essays dealing with pacifism, socialism, and progressive social issues, such as the consequences of war, like the case of the Spanish-American War. In addition, Bates was also an admirer of President Woodrow Wilson and his defense of peace and progressive legislation (1900: 261).

${ }^{15}$ A meeting dedicated to denounce the brutal repression by the government of union workers and social protesters: «Our Madrid mass meeting was of chief consequence in impressing the Government with the weight of popular opinion. The swaying multitude was called to order at quarter of ten by Señor Canalejas, who introduced a notable array of speakers. There were representatives of labor, [...] Pablo Iglesias by name, and great men of the nation, Azcárate, Moret, and Salmerón. [...] But surely there is hope for Spain, while she has sons who, in grasp of a military tyranny which has rendered such crimes possible, contend in open field for the overthrow of the 'black Spain' of the Inquisition, and still bear heart of hope for a white, regenerated Spain, where religion shall include the love of man» (1900: 212-213).

${ }_{16}$ Burgess's description of Bates, far from the reality of her texts and letters, offers this version: «She herself was always a conservative who limited herself to a deprecation of certain class distinctions -an attitude which might be described as a matter of taste and courtesy rather than a political position» (1952: 111-112). 
what informs her project of political activism. Her social protests against political oppression and abuse by higher classes is present on multiple occasions: her description of the Basque workers (1900: 2), the misery of farmers (1900: 4), the wealth of the clergy versus the poverty of the people $(1900: 35,57,90)$, the high level of illiteracy in the population and the living conditions of poor people (1900: $189,428)$, as well as the harsh reality of beggars (1900: 187, 286, 392). In addition, Bates presents the paradox of the high class aristocrats who enjoy the picturesque beauty of unused fields, latifundios, caused precisely by the rich landowners who keep them uncultivated. The desperation of the misery among farmers is clearly present in Bates's dialogue with a young hopeless Spaniard: «-And a fertile soil. What country outblooms Andalusia?» [...] - «Soil! Yes. All the world has soil. It serves to be buried in» (1900: 34).

At this point, it is interesting to see how Bates disengages herself from previous pro-expansionism and imperialistic discourse. Earlier visitors in Spain, such as Alexander Slidell Mackenzie, had advocated territorial, economical and ideological US expansionism. Gifra-Adroher comments on Mackenzie's 1836 travelogue: "[Mackenzie is the] epitome of the emerging American expansionist mentality of Manifest Destiny at a time when this concept had not yet been explicitly formulated» (2000: 97). According to Nigel Leask, the picturesque is a category that filters through association and memory: either due to "personal nostalgia or to imperial desires» (2002: 175-176). Additionally, Stephen Copley and Peter Garside point out how picturesque aesthetics translates the political and the social into the decorative, for example when describing poverty and social deprivation. It is at this point that the picturesque intersects with the discourses of colonialism (1994: 6). In Bates's case, there is an explicit criticism of the imperialism of the United States:

I did not try to explain our new Imperialism in Spanish. It troubles me not a little to understand it in English [...] Catholic Spain, best beloved of Our Lady among the nations of the earth, had labored long in the Philippines to Christianize the heathen, when suddenly, in the midst of those pious labors with which she was too preoccupied to think of fitting out men-of-war and drilling gunners, a pirate fleet bore down upon her and overthrew at once the Spanish banner and the Holy Cross (quoted in Ponder 2017: 180).

With regard to expansionism, Jennifer B. Steadman comments on how women writers practice an unconventional form of nation-building that insists on critiquing the practice of the nation and exposing its limitations and contradictions rather than uncritically advocating expansion. These writers claim authority to criticize the political, social, and economic policies and practices of the nation. Their support of the United States is contingent upon their ability and authority to make and publish their criticisms; only then do they endorse the spread of a reformed and truly democratic nation (2007: 19). In this respect, Fish states that the women writing against expansionism made a special effort to participate meaningfully in the public sphere and to articulate more than just public policies, and for that purpose they journeyed to outposts of conflict and imperial expansion (2004: 3), such 
is the case of Bates. Bates is indeed an agent of expansionism, not economic but educational ${ }^{17}$. She comments on the group of American teachers who came to Spain to work on women's education: «a gallant little band of American teachers spending youth and strength in their patient campaign for conquering the Peninsula by a purer idea of truth. Rough Riders may be more pictorial, but hardly more heroic» (1900: 1). Bates was, indeed, an agent of educational expansionism for women in Europe as the director of the International Institute from 1899 onwards, where she contributed to substantial changes in the education of many young Spanish women.

Another recurrent use of the term picturesque is the traveler's fixation in imagining rustic communities untouched by modernity. The unsophisticated, traditional, and aged was picturesque to their eyes just because it reminded them of the reality back home prior to the emergence of the Industrial Revolution. When visiting Spain, most writers idealized the Peninsula as an old and traditional location, untouched by the dehumanizing tentacles of modernity and industrialization. Most of the traditions fading away back home were still, fortunately, alive in Spain. Some of these travel books idealize rural picturesque Spain but at the same time demonize the country and its people: «In due time they came to seek in the Levant, particularly among the farmers/country men, that ideal of a pristine, long lost unitary community so hard even to imagine at home» (Olsaretti 2007: 269). The economically productive activities of Spain are thus dismissed as un-picturesque and contribute to establishing the troubling division between the backward colonial subject and the productive utility of the foreign traveler. What most travelers expected to encounter in mystified Spain was a stereotypical isolated and backward country, fit for their narratives of picturesque adventures. For that simplistic reason, anything modern could not be picturesque, and vice versa.

In this regard, it is interesting to analyze how Bates comments on the «industry» of Spanish society just upon arrival in the country (1900: 2). In fact, what the reader finds in the first chapter are factories and industrial landscape: modernity at its best. Not everything is going to be picturesque primitivism and bucolic backwardness as expected by tourists. Upon entering Bilbao, Bates comments: «It is not a city to gratify the mere tourist, who expects the people of the lands through which he is pleased to pass to devote themselves to looking picturesque. But even Spain is something more than food for the Kodak» (1900: 373).

To sum up, Bates's attitude towards the picturesque, and towards prejudices and stereotypes, can be summarized with her radical statement in chapter IX: "I have a prejudice against being prejudiced» (1900: 120). It is interesting to observe how Bates foreshadows contemporary theories of discourse and representation. She is aware of and critiques the naive belief in the possibility of language ever simply

17 Bates's will for an improvement in women's education and working conditions becomes evident with her volunteer work. She was a volunteer in Denison House, Boston, a woman-run settlement house which offered social and educational help to immigrants and poor people. She also edited the journal The Courant in which she dedicated her efforts in fighting for women's rights. 
representing the world. All images of the world are just that, images, and not the world itself. Representations bring the world into being. Paraphrasing Roland Barthes, when we encounter representations we do not encounter a world but rather witness the adventure of language. In fact, it is now that people have abandoned a belief in the authenticity of national characters as explanatory models that the actual emergence of imagology as a critical study of national characterization can take place, as commented by Leerssen (quoted in Beller \& Leerssen 2007: 21).

As a woman of her time subject to the frame of imperial discourse, Bates writes on both sides of the liminal line of travel: at times she is complicit with dominant stereotypes about Spain and the conceptions about the other, and on other occasions she recycles those stereotypes and becomes a counter figure of imperial politics. Once again, Bates has no option but to use the existing discourse of the picturesque. In that respect, Elizabeth Bohls comments that many women writers stand in a deeply ambivalent relation to aesthetic discourse and its cultural power but that does not prevent them from challenging this masculine bias (1995: 123). Bates offers examples of the expansionist politics of the United States and the drawbacks of capitalism, but at the same time is unable to divest herself of the imperial gaze of writing as an American intellectual from a high social status. Bates's conflicted position vis-á-vis empire building and her North American inescapable self may be viewed as mediating between her dismissal of some things associated with the United States and her praise of the Spanish counter-picturesque.

What ultimately matters in Spanish Highways and Byways is not the formulation of previous or current stereotypes but rather how the text points out the existence of picturesque prejudices and the need to become critically aware of them. The most useful tool against inherited prejudices is not the vain effort to abolish them but the determination to bring them into the light of day. Imperial politics set about organizing Spain for consumption in the metropolis through the frame of the picturesque. However, the picturesque viewing in Bates represents another manner of enclosing and framing Spanish denizens. Through her mobile subjectivity and social activism, Bates offered significant revisions not only in the portrayal of Spain but also in the aesthetics of travel writing and the rhetoric of representation.

In conclusion, Bates's engagement with travel literature precepts gave her a means of presenting alternative views which facilitated access to a debate about Spain and the picturesque that, like the field of travel writing, had been dominated by men. Bates enters public debate through the back door, that is, with her use of the travel genre. What Spanish Highways and Byways succeeds in doing is to reflect on the rhetorical devices of the genre itself. Travel writing conceived as a general description of a foreign country for readers expecting the stereotypical picturesque was giving way to more specific kinds of writing: social and historical travelogues reflecting on political vindications. All this is at stake in Spanish Highways and Byways, in addition to the traditional description of monuments and customs. By contesting the approaches of other travelers, Bates claims authority in pointing out biases in the stereotypical vision on Spain. As we study Bates's contribution in the construction of the image of Spain through the use of the counter-picturesque, we can begin to map and underline the significant contributions she made on issues 
such as women's rights and education and the public debates on social movements and political activism. Therefore, it is possible to affirm that Bates participated in reshaping Spain's national imagology in this second key moment of the construction of the country's image. By unveiling the hidden picturesque in Bates's discourse, it is possible to see how she rewrote the stereotypical view on Spain and managed to offer an alternative understanding of Spaniards.

Recibido: junio de 2018; ACEPTADo: octubre de 2018. 


\section{BIBLIOGRAPHY}

Andrews, Malcolm (2010): «Dickens, Turner and the Picturesque», in Catherine Waters, Michael Hollington and John Jordan (eds.), Imagining Italy: Victorian Writers and Travelers, Newcastle: Cambridge Scholars Publishing, 177-194.

Barthes, Roland (1989): The Rustle of Language, Berkeley and Los Angeles: University of California Press.

Bates, Katharine Lee (1899a): «Hardships of the Middle Class», The New York Times 12 February: 12.

Bates, Katharine Lee (1899b): «On the Spanish Frontier; An American Woman's Observations in Biarritz; Scars Left by the Late War; Oppression of the Spanish Middle Classes; A Convent Whose Inmates Rarely Speak», The New York Times 12 February: 7.

Bates, Katharine Lee (1900): Spanish Highways and Byways, New York: The Macmillan Company.

Beller, Manfred and Joep Leerssen (eds.) (2007): Imagology: The Cultural Construction and Literary Representation of National Characters - A Critical Survey, Amsterdam and New York: Rodopi.

BoHls, Elizabeth A. (1995): Women Travel Writers and the Language of Aesthetics, 1716-1818, Cambridge: Cambridge University Press.

Bourdieu, Pierre (2000): «The Aesthetic Sense as the Sense of Distinction», in Juliet Schor and Douglas B. Holt (eds.), The Consumer Society Reader, New York: The New Press, 205-211.

Braham, Persephone (2002): «Adventures in the Picturesque: Voyage and Voyerism in the Tourist Guidebook to Mexico», Revista Canadiense de Estudios Hispánicos 16 (3): 379-394.

Brooke, Arthur (1831): Sketches in Spain and Morocco, London: Henry Colburn and Richard Bentley.

Burgess, Dorothy W.B. (1952): Dream and Deed: The Story of Katharine Lee Bates, Norman: University of Oklahoma Press.

Buzard, James (1993): The Beaten Track: European Tourism, Literature, and the Ways to Culture, 1899-1918, Oxford: Oxford University Press.

Combe, William (1812): The Tour of Doctor Syntax in Search of the Picturesque, London: R. Ackermann.

Copley, Stephen and Peter Garside (1994): The Politics of the Picturesque, Cambridge: Cambridge University Press.

Egea Fernández-Montesinos, Alberto (coord.) (2009): Viajeras anglosajonas en España: una antología, Sevilla: Centro de Estudios Andaluces.

Fish, Cheryl J. (2004): Black and White Women's Travel Narratives, Gainesville: University Press of Florida.

Foster, Shirley and Sara Mills (eds.) (2002): An Anthology of Women's Travel Writing, Manchester: Manchester University Press.

Friedman, Susan Stanford (1998): Mappings: Feminism and the Cultural Geographies of Encounter, Princeton: Princeton University Press.

Gifra-Adroher, Pere (2000): Between History and Romance: Travel Writing on Spain in the Early Nineteenth-Century United States, Madison: Fairleigh Dickinson University Press.

Gilpin, William (1792): Three Essays: on Picturesque Beauty; on Picturesque Travel; and on Sketching Landscape: to which is Added a Poem, on Landscape Painting, London: R. Blamire. 
Harper, Lila Marz (2001): Solitary Travelers. Nineteenth-Century Women's Travel Narratives and the Scientific Vocation, Madison: Fairleigh Dickinson University Press.

Kinsley, Zoë (2005): «Dorothy Richardson's Manuscript Travel Journals (1761-1801) and the Possibilities of Picturesque Aesthetics", The Review of English Studies 56: 611-631.

Knight, Richard Payne (1805): An Analytical Inquiry into the Principles of Taste, London: T. Payne.

Leask, Nigel (2002): Curiosity and the Aesthetics of Travel Writing, 1770-1840, Oxford: Oxford University Press.

Marshall, David (2005): The Frame of Art. Fictions of Aesthetic Experience, 1750-1815, Baltimore: The John Hopkins University Press.

Olsaretti, Alessandro (2007): «Urban Culture, Curiosity and the Aesthetics of Distance: The Representation of Picturesque Carnivals in Early Victorian Travelogues to the Levant", Social History 32 (3): 247-270.

Ortas Durand, Esther M. (1999): «El pintoresquismo de personas, tipos e indumentarias aragoneses según los viajeros de la primera mitad del siglo XIX», in José Carlos Mainer and José María Enguita Utrilla (eds.), Localismo, costumbrismo y literatura popular en Aragón, Zaragoza: Institución Fernando el Católico, 173-200.

Ponder, Melinda M. (2017): Katharine Lee Bates: From Sea to Shining Sea, Chicago: Windy City Publishers.

Pratt, Mary L. (1992): Imperial Eyes: Studies in Travel Writing and Transculturation, London: Routledge.

Price, Uvedale (1810): Essays on the Picturesque, as Compared with the Sublime and the Beautiful, London: J. Mawman.

Roberts, David (1837): Picturesque Sketches in Spain Taken during the Years 1832 \& 1833, London: Hodcson \& Graves.

Steadman, Jennifer B. (2007): Traveling Economies. American Women's Travel Writing, Colombus: Ohio State University Press.

TAylor, Bayard (1875-1879): Picturesque Europe: a Delineation by Pen and Pencil of the Natural Features and the Picturesque and Historical Places of Great Britain and the Continent, New York: Appleton.

Watkin, David (1982): The English Vision: the Picturesque in Architecture, Landscape, and Garden Design, New York: Harper \& Row. 